\title{
Kontakty filmowe pomiędzy Polską Rzeczypospolitą Ludową a Czechosłowacką Republiką Socjalistyczną w latach 70. XX wieku
}

Przedmiotem niniejszego artykułu są polsko-czechosłowackie związki filmowe z lat 70. XX wieku, rozpatrywane z punktu widzenia ówczesnych stosunków politycznych i kulturalnych między państwami na tle uwarunkowań historycznych.

Współpracę kulturalną w tzw. dekadzie gierkowskiej (1971-1980) rozwijano dzięki umowie pomiędzy rządem Polskiej Rzeczypospolitej Ludowej (PRL) a rządem Czechosłowackiej Republiki Socjalistycznej (CSRS) podpisanej w Warszawie dnia 22 stycznia 1966 roku i automatycznie przedłużanej co pięć lat, jak również na podstawie dwuletnich planów wykonawczych do umowy i w oparciu o plan realizacji umowy o współpracy kulturalnej na lata 1976-1980 podpisany w Pradze 20 listopada 1975 roku ${ }^{1}$. Umowa z 1966 roku zastępowała umowę o współpracy kulturalnej między Rzecząpospolitą Polską a Republiką Czechosłowacką podpisaną w Pradze 4 lipca 1947 roku². Jeśli chodzi o podstawy współpracy filmowej,

* Uniwersytet Kazimierza Wielkiego w Bydgoszczy.

1 Dz. U. 1966 r. nr 32, poz. 190; Janina Bilińska, Stosunki między Polska a Czechostowacja, [w:] Stosunki Polski z innymi państwami socjalistycznymi, red. Czesław Mojsiewicz, Państwowe Wydawnictwo Naukowe, Warszawa 1973, s. 76; Bogusław Płaza, Kultura zbliża narody. O wspótpracy kulturalnej Polski z zagranica w latach 1945-1976, Książka i Wiedza, Warszawa 1978, s. 119, 167.

${ }^{2}$ Choć stosunki polsko-czechosłowackie po II wojnie światowej kształtowało wiele kwestii spornych (terytorialnych i ludnościowych) dość szybko udało się uregulować związki w dziedzinie kultury. Przełomowym w tym zakresie było spotkanie w Pradze w sierpniu 1945 roku z przedstawicielami Poselstwa RP, Ministerstwa Informacji i Propagandy, a także polskich, czeskich i słowackich środowisk twórczych. Dwa lata później, 4 lipca 1947 roku, podpisano w Pradze umowę o współpracy kulturalnej między Rzecząpospolitą Polską a Republiką Czechosłowacka, która zakładała m.in. powołanie Instytutów Kultury i popularyzację wzajemną dorobku kulturalnego oraz zbliżenie środowisk twórczych. Zob. Anna Szczepańska, Warszawa - Praga 1948-1968. Od nakazanej przyjaźni do kryzysu, Wydawnictwo Naukowe Uniwersytetu Szczecińskiego, Szczecin 2011, s. 200-201; Anna Szczepańska-Dudziak, Polsko-czechosłowackie kontakty kulturalne i naukowe 1945-1956, „Historia Slavorum Occidentis” 2015, nr 1, s. 212-214. 
regulowały ją ponadto bezpośrednie plany współpracy podpisywane każdego roku przez Naczelny Zarząd Kinematografii i „Czechosłowacki Film". Porównując z innymi krajami socjalistycznymi, uwagę zwraca rutynowy charakter tego typu dokumentów, który w toku realizacji postanowień próbowano przełamywać cechami narodowymi ${ }^{3}$. Jednak zanim omówię założenia umów PRL-CSRS i ich praktyczną realizację, za celowe uważam uwzględnienie krótkiego rysu historycznego, przedstawiającego związki sąsiedzkie kinematografii z lat 1945-1970.

\section{1.}

W okresie bezpośrednio powojennym szczególną dynamiką charakteryzowały się kontakty w dziedzinie literatury, jednak na nie mniej „,wysokim poziomie" rozwijała się współpraca filmowa ${ }^{4}$. Już 6 sierpnia 1945 roku z inicjatywy polskiego resortu Propagandy Filmowej Aleksander Ford i Jerzy Toeplitz podjęli próby nawiązania bezpośredniej współpracy z czechosłowackim przemysłem filmowym (w przeciwieństwie do polskich struktur kinematograficznych, wytwórnia filmowa Barrandov, określana jako „słowiańskie Hollywood", przetrwała wojnę w zasadzie bez strat materialnych i osobowych) $)^{5}$. Kontakty sformalizowano w 1947 roku. Na podstawie porozumień zawartych przez Czechosłowackie Towarzystwo Filmowe i Przedsiębiorstwo Państwowe „Film Polski”, dotyczących przywozu czechosłowackich filmów do Polski i wywozu polskich filmów do Czechosłowacji, zapoczątkowano wymianę filmową. Jednymi z pierwszych filmów „bratanków" wyświetlanych w Polsce były: Syrena (Siréna, reż. Karel Steklý, 1947), Jan Rohacz z Dube (Jan Roháč z Dubé, reż. Vladimír Borský, 1947) i Nikt nic nie wie (Nikdo nic neví, reż. Josef Mach, 1947), a z kolei w Czechosłowacji: Ostatni etap (1947, reż. Wanda Jakubowska), Zakazane piosenki (1946, reż. Leonard Buczkowski) i Za wami pójda inni... (1949, reż. Antoni Bohdziewicz) ${ }^{6}$.

${ }^{3}$ Zob. np. Zdzisław Biegański, Kino puli specjalnej: filmy jugosłowiańskie na ekranach kin Polski Ludowej, [w:] Polska i Jugosławia w stosunkach międzynarodowych po II wojnie światowej, red. Momcilo Pavlović, Andrzej Zaćmiński, Wydawnictwo Uniwersytetu Kazimierza Wielkiego, Bydgoszcz 2014; Joanna Szczutkowska, Wspótpraca kulturalna Polski z Jugosławia $w$ dziedzinie kinematografii w latach siedemdziesiatych XX wieku, [w:] Polska i Jugostawia po II wojnie światowej, red. Momcilo Pavlović, Nebojsa Stambolija, Andrzej Zaćmiński, Wydawnictwo Uniwersytetu Kazimierza Wielkiego, Bydgoszcz 2016.

${ }^{4}$ Anna Szczepańska-Dudziak, Polsko-czechosłowackie kontakty..., s. 224.

5 Szerzej: Jana Homolka Zelinová, Československo-polské kulturní styky 1945-1948, Uniwersytet Masaryka, Brno 2016, s. 88.

6 Tamże, s. 92-93; Anna Szczepańska-Dudziak, Polsko-czechosłowackie kontakty..., s. 224-225. 
Repertuar gatunkowy prezentowanych filmów był zróżnicowany; widzowie mogli obejrzeć utwory cieszące się międzynarodowym uznaniem, jak np. Ludzie bez skrzydeł (Muži bez kř́́del, reż. František Čáp, 1946), jednak większość z nich była obciążona ideologicznie i ze względu na niskie walory artystyczne nie zyskała szerszego rozgłosu. Pod wpływem socrealizmu, który, jak to ujął Tadeusz Miczka, utrudniał rozwój kinematografii (i kultury w ogóle), wymiana filmowa przebiegała w tym okresie „wyjątkowo schematycznie" ${ }^{\prime \prime}$. Z dzisiejszej perspektywy ciekawym świadectwem polsko-czechosłowackich kontaktów filmowych z pierwszych lat powojennych jest współpraca reżysera Aleksandra Forda i operatora Jaroslava Tuzara przy filmie Ulica Graniczna (1948, reż. Aleksander Ford) - zrealizowanym w dużej mierze dzięki zaangażowaniu czeskich filmowców w atelier studia Barrandov ${ }^{8}$, kontynuowana w kolejnej dekadzie przy filmach Młodość Chopina (1952) oraz Piątka z ulicy Barskiej (1954) ${ }^{9}$.

W latach powojennych można zaobserwować największe różnice produkcyjne między kinematografiami; przewaga CSRS w tym zakresie będzie utrzymywać się aż do końca lat 80. Przykładowo, jeśli w 1950 roku Czechosłowacja wyprodukowała 20 filmów fabularnych, w 1961 - 39, a w 1971 - 59, to w Polsce powstało ich odpowiednio: 4, 24 i 25. Jak zauważa Tadeusz Miczka, taka sytuacja tłumaczy w pewien sposób fakt, że dystrybutorzy polscy kupowali więcej filmów niż czechosłowaccy ${ }^{10}$. Do tego wątku powrócę w dalszej części rozważań.

W 1956 roku pod wpływem wydarzeń polskiego Października (VIII Plenum KC, odnowienie władz partyjno-rządowych i liberalizacja systemu ${ }^{11}$ ) nastąpiło ograniczenie dwustronnych stosunków filmowych. W Czechosłowacji bardzo negatywnie zareagowano na odwilż gomułkowską, interpretując ją jako „śmiertelne zagrożenie” dla ustroju i ludzi sprawujących władzę. Chłodniejsze stały się nie tylko polityczne stosunki partyjno-państwowe. Praga nie akceptowała przemian, jakie zaszły w polskim życiu kulturalnym. Starano się odciąć tamtejsze społeczeństwo od

7 Tadeusz Miczka, Kino czeskie w Polsce i kino polskie w Czechosłowacji w okresie realnego socjalizmu (1945-1989), [w:] Czechy i Polska na szlakach ich kulturalnego rozwoju, red. Jerzy Wyrozumski, Międzynarodowe Centrum Kultury, Kraków 1998, s. 253-254, 259.

8 Szerzej na temat polsko-czechosłowackich prac nad filmem zob. Jana Homolka Zelinová, Československo-polské kulturní styky..., s. 90-91.

9 Ewa Ciszewska, Trudna sztuka koprodukcji. O pierwszym powojennym filmie polsko-czechosłowackim "Zadzwońcie do mojej żony" (1958) Jaroslava Macha, „Kwartalnik Filmowy” 2016, nr 96, s. 164.

10 Tadeusz Miczka, Kino czeskie w Polsce i kino polskie w Czechostowacji..., s. 252-253.

11 Wojciech Roszkowski, Najnowsza historia Polski 1945-1980, Świat Książki, Warszawa 2003, s. 335-421. 
informacji na temat przemian w Polsce i ograniczyć kontakty między przedstawicielami świata kultury i sztuki ${ }^{12}$. Imprezy i festiwale filmowe były okazją do krytyki swobody artystycznej sąsiadów. W Karlowych Warach w 1957 roku negatywnie oceniano w prasie polskich twórców za to, że zabrnęli w "ślepą uliczkę" pod nazwą "artystyczna anarchia”. W podobnym tonie brzmiały opinie względem polskich filmowców podczas konferencji pracowników filmowych krajów socjalistycznych, zorganizowanej w Pradze w grudniu 1957 roku $^{13}$.

Stopniowo następowała poprawa relacji. W raporcie Ambasady PRL w Pradze za okres od 1 września 1957 do 1 kwietnia 1958 roku zanotowano:

[...] w ostatnim czasie następił poważny zwrot w stosunkach polsko-czechosłowackich. Obserwuje się wyraźne zaktywizowanie kontaktów oraz dążeń do elimowania zastrzeżeń i spraw dyskusyjnych. W praktycznym działaniu nie wysuwa się już różnic między naszymi krajami, a podkreśla się raczej wszystkie łączące je więzy ${ }^{14}$.

Kilka miesięcy po opracowaniu powyższego raportu, 20 grudnia 1958 roku, miała miejsce premiera pierwszej po II wojnie światowej polsko-czechosłowackiej koprodukcji pt. Zadzwońcie do mojej żony (Co řekne žena, 1958, reż. Jaroslav Mach), którą zdaniem Ewy Ciszewskiej można uznać „nie tylko jako summę ówczesnych stereotypów i wiedzy o sąsiadach, ale także jako wyraz oficjalnej polityki kulturalnej"15. Dobrą passę w stosunkach z Czechosłowacją opisano w raporcie Ambasady PRL w Pradze za okres od stycznia do września 1959 roku, gdzie stwierdzono ponadto, że "tegoroczny plan jest najszerszym z dotychczas podpisanych między naszymi krajami oraz najszerszym z planów wymiany kulturalnej CSR z innymi krajami demokracji ludowej"16.

12 Robert Skobelski, Polityka PRL wobec państw socjalistycznych w latach 1956-1970. Wspótpraca - napięcia - konflikty, Wydawnictwo Poznańskie, Poznań 2010, s. 459-460; Anna Szczepańska-Dudziak, Polsko-czechostowackie kontakty..., s. 219.

${ }_{13}$ Magdalena Sirecka-Wołodko, Zagraniczna polityka kulturalna Polski w latach 19561970, Wydawnictwo Mado, Toruń 2011, s. 199-200.

${ }_{14}$ Archiwum Ministerstwa Spraw Zagranicznych (AMSZ), Dep. I, z. 7, w. 55, t. 481, Raport polityczny Ambasady PRL w Pradze za okres 1.09.1957-1.04.1958, cyt. za: Magdalena Sirecka-Wołodko, Zagraniczna polityka kulturalna Polski..., s. 180.

${ }^{15}$ Ewa Ciszewska, Trudna sztuka koprodukcji..., s. 163. Szerzej na temat filmu zob. tamże, s. 162-174.

16 AMSZ, Dep. I, z. 7, w. 55, t. 482, Raport polityczny Ambasady PRL w Pradze za okres styczeń-wrzesień 1959 r., cyt. za: Magdalena Sirecka-Wołodko, Zagraniczna polityka kulturalna Polski..., s. 183. 
Duże znaczenie propagandowe w uregulowaniu i rozwijaniu kontaktów kulturalnych miała wizyta I sekretarza Komitetu Centralnego Komunistycznej Partii Czechosłowacji (KC KPCz) i prezydenta CSRS Antonína Novotnego w Warszawie, we wrześniu 1960 roku. W jednym z przemówień Novotný podkreślił wagę historycznych związków obu narodów, które „żyją obok siebie od tysiąca lat i jako sąsiedzi przeżyły czasy dobre i złe [...] historia świadczy, że zbliżenie to zawsze przynosiło obustronne korzyści i pożytek"17. Z perspektywy Ambasady PRL w Pradze opisywana wizyta czechosłowackiej delegacji oczyściła

[...] pole z wielu wątpliwości, niedomówień i hamulców, jakie przed tym występowały przede wszystkim w dziedzinie współpracy kulturalnej. Obecnie w Czechosłowacji istnieją pełne warunki i klimat, aby poważnie wzbogacić, rozszerzyć i pogłębić współpracę w dziedzinie kultury, nauki i informacji o Polsce. Można powiedzieć, że $\mathrm{w}$ tej dziedzinie rozpoczyna się nowy etap i że w związku z tym dotychczasowe formy wymiany, jak i jej treść oraz zasięg powinny być poddane krytycznej ocenie i po nowemu winny być realizowane ${ }^{18}$.

Początek dekady lat 60. zwiastował zatem pozytywne tendencje, przypieczętowane w sferze kultury nową umową z 1966 roku, której art. 2 przewidywał, że umawiające się strony będą realizować współpracę m.in. przez wymianę filmów i organizowanie przeglądów filmowych ${ }^{19}$. Postanowienia starano się realizować: w 1967 roku z okazji 20. rocznicy podpisania układu o przyjaźni i pomocy wzajemnej zorganizowano Tydzień Filmów Polskich w Czechosłowacji, zaś w marcu 1967 roku w kinie Skarpa w Warszawie odbył się Przegląd Filmów Czechosłowackich. Pokazy filmowe organizowały też instytuty narodowe. $\mathrm{W}$ omawianym roku zaprezentowano w Polsce łącznie 16 pełnometrażowych filmów fabularnych, m.in. Biała panią (Bílá pani, reż. Zdeněk Podskalský, 1965) i Pociagi pod specjalnym nadzorem (Ostře sledované vlaky, reż. Jiří Menzel, 1966), a z kolei w Czechosłowacji wyświetlono ich 13, m.in. Boksera (1966, reż. Julian Dziedzina), Sublokatora (1966, reż. Janusz Majewski) i Jowitę (1967, reż. Janusz

171960 wrzesień 5, Warszawa. Przemówienie I sekretarza Komitetu Centralnego KPCz i prezydenta CSRS A. Novotnego podczas powitania czechostowackiej delegacji partyjno-rzadowej przybyłej z wizyta do Polski, [w:] Dokumenty i materiały do historii stosunków polsko-czechosłowackich, t. I, cz. 2, red. Wiesław Balcerak, Zakład Narodowy im. Ossolińskich, Wrocław 1985, s. 521.

18 AMSZ, DPI, z. 21, w. 31, t. 402, Sprawozdanie kulturalne Ambasady PRL w Pradze za okres 1960 roku do 15 marca 1961 r., cyt. za: Magdalena Sirecka-Wołodko, Zagraniczna polityka kulturalna Polski..., s. 183-184.

19 Dz. U. 1966 r. nr 32, poz. 190. 
Morgenstern). Oznaką ożywienia stosunków było podpisanie w dniu 13 grudnia 1967 roku umowy o współpracy na lata 1968-1969 pomiędzy Ministerstwem Kultury i Sztuki a Dyrekcją Generalną Czechosłowackiego Filmu ${ }^{20}$.

Na dobrze rozwijającej się wymianie filmowej zaważył czynny udział Polski w interwencji wojsk państw Układu Warszawskiego w Czechosłowacji w sierpniu 1968 roku i stłumienie Praskiej Wiosny. Ogromną rolę w przygotowaniach do siłowego rozwiązania „kryzysu czechosłowackiego" odegrał I sekretarz Komitetu Centralnego Polskiej Zjednoczonej Partii Robotniczej (KC PZPR) Władysław Gomułka ${ }^{21}$. Twardogłowy przeciwnik I sekretarza KC KPCz Aleksandra Dubczeka był zdania, że „kłopoty zawsze zaczynają się od artystów”. „Pod flagą obrony kultury i obrony wolności, pod tą maską działa wróg, działa kontrrewolucja" - mówił²2. Polityczna i militarna akcja Gomułki spowodowała wybuch nastrojów antypolskich w CSRS, zauważalnych nawet wśród działaczy $\mathrm{KPC}^{23}$. W odpowiedzi na udział Warszawy w interwencji czechosłowackie związki twórcze zaczęły bojkotować współpracę kulturalną z PRL ${ }^{24}$.

Jak wynika z dotychczasowych rozważań, w dziejach polsko-czechosłowackich związków filmowych okresy rozwoju i poszukiwań nowych formuł przeplatają się z momentami załamania kooperacji na tle napięć politycznych. Kolejna dekada, obejmująca lata tzw. normalizacji w CSRS pod rządami I sekretarza KC KPCz (od 1975 roku także prezydenta) Gustáva Husáka i zmianę na stanowisku I sekretarza KC PZPR, przyniosła poprawę stosunków. Edward Gierek, korzystając z międzynarodowych tendencji odrodzeniowych, otworzył Polskę na Zachód, dbając jednocześnie o tradycyjne dobrosąsiedztwo. W latach 70. XX wieku najbardziej aktywne kontakty Polska - uzależniona od ZSRR - utrzymywała z Bułgaria, Czechosłowacja, NRD, Węgrami oraz Rumunią. Celem nowej ekipy gierkowskiej było, odwołując się do haseł ówczesnej propagandy, „wyrównywanie relacji” z „bratnimi” krajami. W tym celu Polska inicjowała deklaracje o umacnianiu przyjaźni i pogłębianiu współpracy - tego typu dokumenty z Czechosłowacją podpisano 14 marca 1974 roku

${ }^{20}$ Anna Szczepańska, Warszawa - Praga..., s. 453-456.

${ }^{21}$ Szerzej Jerzy Eisler, Siedmiu wspaniałych. Poczet pierwszych sekretarzy KC PZPR, Wydawnictwo Czerwone i Czarne, Warszawa 2014, s. 232-233.

${ }^{22}$ Anthony Kemp-Welch, Polska pod rzadami komunistów 1944-1989, tłum. Joanna Gilewicz, Wydawnictwo Uniwersytetu Jagiellońskiego, Kraków 2008, s. 202.

${ }^{23}$ Robert Skobelski, Polityka PRL wobec państw socjalistycznych..., s. 475.

${ }^{24}$ Magdalena Sirecka-Wołodko, Zagraniczna polityka kulturalna Polski..., s. 188-189. 
i 6 lipca 1977 roku². Udało się zatem wypracować pewną stabilizację, choć stosunki nie były łatwe. Jak pisze Andrzej Skrzypek:

Państwo to odgrywało, abstrahując od relacji z ZSRR, pierwszoplanową rolę w naszej polityce wewnątrz wspólnoty, jakkolwiek ta koncetrowała się na sprawach gospodarczych. Współpracowaliśmy, choć dużo było nieporozumień, zawiści i usiłowań wykorzystania partnera ${ }^{26}$.

Zdaniem ówczesnych analityków wymiana kulturalna uległa wyraźnej poprawie od 1972 roku $^{27}$. Ponowne ograniczenie kontaktów wiąże się z wybuchem kryzysu w Polsce w 1980 roku i obawą kierownictwa KPCz przed rozszerzeniem tendencji antykomunistycznych ${ }^{28}$.

\section{2.}

W tzw. dekadzie gierkowskiej kinematografia zajmowała ważne miejsce $\mathrm{w}$ systemie wymiany kulturalnej PRL z zagranicą ${ }^{29}$, co wiązało się z przekonaniem polityków, że:

Film jest najbardziej uniwersalnym nośnikiem wiedzy o historii, tradycjach kulturalnych, życiu gospodarczo-społecznym i politycznym kraju [...] dociera wszędzie, nawet tam gdzie nie dotarła jeszcze prasa i książka, gdzie nie dotarł teatr ani telewizja, ma najliczniejszą na świecie rzeszę odbiorców [...]. Wszystko wydaje się wskazywać na to, że podstawową płaszczyzną, na której odbywać się będzie konfrontacja ideologiczna między socjalizmem a kapitalizmem - stanie się kultura. Film zajmuje tu poczesne miejsce i będzie miał olbrzymią rolę do odegrania ${ }^{30}$.

${ }^{25}$ Justyna Zając, Ryszard Zięba, Polska w stosunkach międzynarodowych 1945-1989, Wydawnictwo Adam Marszałek, Toruń 2005, s. 128-129; Andrzej Skrzypek, Dyplomatyczne dzieje PRL w latach 1956-1989, Akademia Humanistyczna im. A. Gieysztora, Oficyna Wydawnicza ASPRA-JR, Pułtusk-Warszawa 2010, s. 191-194.

26 Andrzej Skrzypek, Dyplomatyczne dzieje PRL..., s. 194.

27 Bogusław Płaza, Kultura zbliża narody..., s. 119.

${ }_{28}$ Jan Rychlík, Społeczeństwo czechosłowackie i Komunistyczna Partia Czechosłowacji a wydarzenia w Polsce w latach 1980-1981, tłum. Manuela Maciołek, [w:] Między przymusowa przyjaźnia a prawdziwa solidarnościa. Czesi - Polacy - Słowacy 1938/39-1945-1989, red. Petr Blažek, Paweł Jaworski, Łukasz Kamiński, Instytut Pamięci Narodowej - Komisja Ścigania Zbrodni przeciwko Narodowi Polskiemu, Warszawa 2009, s. 207-220.

${ }^{29}$ Szerzej na ten temat zob. Joanna Szczutkowska, Polityka kulturalna PRL $w$ dziedzinie kinematografii w latach 70., Wydawnictwo Uniwersytetu Kazimierza Wielkiego, Bydgoszcz 2014, s. 256-330.

${ }^{30}$ Archiwum Akt Nowych (AAN), Naczelny Zarząd Kinematografii (NZK), sygn. 1/109, Perspektywiczny program działania polskiej kinematografii za granicą (1974). 
Kierunki międzynarodowej działalności filmowej określano zgodnie z celami polityki zagranicznej PRL. Jak wynika z dokumentu NZK pt. Perspektywiczny program działania polskiej kinematografii za granica, Czechosłowacja zajmowała drugi po ZSRR priorytetowy kierunek zagranicznej polityki filmowej kraju ${ }^{31}$.

Współpraca filmowa Polski z Czechosłowacją opierała się w latach 70. XX wieku na podpisywanych każdego roku Planach Współpracy między Ministerstwem Kultury i Sztuki - Naczelnym Zarządem Kinematografii a „Czechosłowackim Filmem”. Przebiegała wielokierunkowo, zakładając rozmaite formy kontaktów, a wśród nich nade wszystko:

- koprodukcje i wzajemne świadczenie usług filmowych,

- organizację uroczystych premier z okazji świąt narodowych,

- wzajemne organizowanie przeglądów i "dni filmu”,

- uczestnictwo obu kinematografii w międzynarodowych imprezach odbywających się w Polsce i Czechosłowacji,

- wymianę materiałów filmowych i współpracę filmotek,

- wymianę doświadczeń w poszczególnych pionach kinematografii,

- współpracę stowarzyszeń filmowców - pracowników twórczych i technicznych ${ }^{32}$.

Poczesne miejsce w kształtowaniu powyższych planów odgrywały tradycyjne doroczne narady szefów kinematografii krajów socjalistycznych $^{33}$. Historia międzynarodowych konferencji filmowych $\mathrm{w}$ bloku wschodnim sięga lat 50. XX wieku i wiąże się z dążeniem ZSRR do skoordynowania oraz kontrolowania państwowych przemysłów i kultury filmowej. Pavel Skopal określa je jako „instytucje dyscyplinujące”, które miały przyczyniać się do tworzenia socjalistycznego kina transnarodowego $^{34}$. Idee organizowania konferencji kontynuowano $\mathrm{w}$ kolejnych dekadach.

Jedno z tego typu posiedzeń odbyło się w Polsce w dniach 11-12 lutego 1975 roku. W Warszawie spotkały się delegacje kierownictw „brat-

31 Tamże.

32 AAN, NZK, sygn. 2/185, Współpraca polsko-czechosłowacka w dziedzinie kinematografii w latach 1972-1973; Kronika, „Filmowy Serwis Prasowy” 1979, nr 6, s. 30.

${ }_{33}$ Por. Edward Zajiček, Film polski. Ekonomika i organizacja produkcji, Państwowe Wydawnictwo Naukowe, Warszawa 1983, s. 100-101.

${ }^{34}$ Szerzej na ten temat zob. Pavel Skopal, Międzynarodowa konferencja jako instytucja dyscyplinująca. "Rewizjonistyczne tendencje" w polskim kinie lat 1957-1960 z perspektywy radzieckiej, tłum. Miłosz Stelmach, [w:] Kino polskie jako transnarodowe, red. Sebastian Jagielski, Magdalena Podsiadło, Universitas, Kraków 2017, s. 127-137. 
nich" kinematografii i filmowych stowarzyszeń twórczych ${ }^{35}$. Dyrektor generalny Kinematografii Czechosłowackiej Jiří Purš ${ }^{36}$, omawiając niektóre podstawowe dane dotyczące stosunków CSRS z zagranica, wspomniał wówczas o wspólnym filmie realizowanym z kinematografią polską pt. Podwójny świat w hotelu Pacyfik (Dvojí svět hotelu Pacifik) ${ }^{37}$, o czym szerzej w dalszej części tekstu.

Wymianie informacji i koordynowaniu współpracy sprzyjały kontakty na forum międzynarodowym: spotkania przy okazji zebrań organizacji międzynarodowych i specjalistycznych konferencji konsultacyjnych, festiwali i okolicznościowych imprez filmowych. Przykładowo, w 1974 roku w Warszawie odbyła się narada pracowników filmotek krajów socjalistycznych $^{38}$. Zaangażowanie narodowych archiwów filmowych (Filmoteka Polska i Československý filmový ústav) w promowanie wzajemne twórczości filmowej było w tym czasie zauważalne. Wspomnieć można np. współpracę przy organizacji przeglądu filmów Vladislava Vančury w warszawskim "Iluzjonie" ${ }^{39}$.

Jedną z oficjalnych okazji, aby potwierdzić rozwojową współpracę, wyznaczył jubileusz 30-lecia kinematografii polskiej. Dla jego uczczenia dyrektor Kinematografii Czechosłowackiej Jiří Purš wystosował,

35 Oprócz Polskiej Rzeczypospolitej Ludowej i Czechosłowackiej Socjalistycznej Republiki w naradzie uczestniczyły delegacje Bułgarskiej Republiki Ludowej, Niemieckiej Republiki Demokratycznej, Socjalistycznej Republiki Rumunii, Węgierskiej Republiki Ludowej oraz Związku Socjalistycznych Republik Radzieckich - AAN, NZK, sygn. 1/106, Stenogram z narady kinematografii krajów socjalistycznych odbytej w dniu 11 lutego 1975 roku w Warszawie.

${ }^{36}$ W składzie delegacji Czechosłowackiej Republiki Socjalistycznej znaleźli się ponadto: Ján Podhradský - dyrektor Kinematografii Słowackiej, Jaromila Hrůzová - pracownik KC KPCz, Jiří Rybín - dyrektor filmowego przedsiębiorstwa handlu zagranicznego, Ludvík Toman - członek Prezydium Czechosłowackiego Związku Artystów Dramatycznych, Leo Štefankovič - przedstawiciel Związku Filmowców Słowacji, Jan Vaníček - zastępca naczelnika wydziału zagranicznego, Jaromíra Mizerová - pracownik wydziału zagranicznego. Z kolei w składzie Polskiej Rzeczypospolitej Ludowej znaleźli się: Mieczysław Wojtczak - I zastępca Ministra Kultury i Sztuki, Jan Kasak - zastępca kierownika Wydziału Kultury KC PZPR, Jerzy Kawalerowicz - prezes Stowarzyszenia Filmowców Polskich, Jerzy Bajdor - dyrektor NZK, Wacław Janas - dyrektor NZK, Stanisław Kuszewski - rektor PWSFTiT w Łodzi, Alicja Ciężkowska - dyrektor "Filmu Polskiego” - AAN, NZK, sygn. 1/107, Dokument końcowy narady szefów kinematografii krajów socjalistycznych. Warszawa, 11-12 luty 1975.

37 AAN, NZK, sygn. 1/106, Stenogram z narady kinematografii krajów socjalistycznych odbytej w dniu 11 lutego $1975 \mathrm{w}$ Warszawie. Wspomniany film w Polsce rozpowszechniano pt. Zaklęte rewiry.

${ }^{38}$ Joanna Szczutkowska, Polityka kulturalna PRL..., s. 282.

39 Kronika, "Filmowy Serwis Prasowy” 1979, nr 4, s. 25. 
podobnie jak przedstawiciele pozostałych „bratnich krajów”, specjalne "pozdrowienia":

\begin{abstract}
My, pracownicy „Filmu Czechosłowackiego” przekazujemy najserdeczniejsze życzenia wszystkim pracownikom twórczym, technicznym i administracyjnym, robotnikom i całemu kierownictwu kinematografii Polskiej Rzeczypospolitej Ludowej z okazji trzydziestej rocznicy powstania kinematografii państwowej [...]. Jesteśmy przekonani, że w ścisłej współpracy z pozostałymi kinematografiami socjalistycznymi, polska kinematografia tworzyć będzie nadal filmy ukazujące w sposób prawdziwy i artystycznie wartościowy życie społeczeństwa socjalistycznego, i w ten sposób przyczyni się do wspólnego, dalszego pogłębiania przyjaźni i współpracy między narodami, do umocnienia pokoju i dalszego rozkwitu socjalistycznej sztuki filmowej ${ }^{40}$.
\end{abstract}

Praktyczną realizację planów współpracy dwustronnej komplikowała złożona sytuacja wewnętrzna w CSRS i w czechosłowackim filmowym środowisku twórczym, zaistniała w następstwie wydarzeń 1968 roku. Interwencja wojsk Układu Warszawskiego wymusiła anulowanie reform i odsunięcie reformatorów, paraliżując tamtejsze życie polityczne i kulturalne $^{41}$. Spowodowała uwiąd czechosłowackiej nowej fali (1963-1968), której także w Polsce przewidywano pod koniec dekady ciekawą przyszłość: „Film czechosłowacki jest w stadium nieustannego rozwoju, nic nie wróży wyczerpania się twórczej inwencji reżyserów"42 - pisano. Ten „cud filmowy" - twierdzi znawczyni kinematografii środkowoeuropejskiej Dobrochna Dabert - „przygasł potem na wiele dekad, pozostając w czasie panowania tandetnej sztuki normalizacyjnej jedynie legendą bez szans na kontynuację jej artystycznego przesłania" ${ }^{\prime 3}$. Większość nowofalowych filmów na wiele lat stało się „półkownikami” ${ }^{44}$. Tego typu represje dotykały także twórców kultury w innych krajach socjalistycznych i z tego względu $\mathrm{w}$ polskiej literaturze przedmiotu zwraca się czasem uwagę na analogię między opisaną sytuacją a reakcją władz PRL na polską szkołę filmową ${ }^{45}$.

40 Jiří Purš, XXX lat kinematografii, „Kino” 1976, nr 1, s. 8-9.

${ }^{41}$ Peter Calvocoressi, Polityka międzynarodowa 1945-2000, tłum. Wiesława Bolimowska-Garwacka, Hanna Burska, Stanisław Głąbiński, Janusz Gołębiowski, Książka i Wiedza, Warszawa 2002, s. 324.

${ }^{42}$ Janusz Skwara, Nowy film czechosłowacki, Wydawnictwo Artystyczne i Filmowe, Warszawa 1968, s. 87.

${ }^{43}$ Dobrochna Dabert, Fenomen Czechosłowackiej Nowej Fali, [w:] Czechosłowacka Nowa Fala, red. Marzena Matla, Lenka Németh Vítová, Instytut Historii UAM, Poznań 2012, s. 13.

${ }^{44}$ Ewa Ciszewska, Filmy nie do końca "normalne": z historii czechosłowackiej "normalizacji”, ,Kino" 2010, nr 10, s. 64.

${ }^{45}$ Dorota Skotarczak, Czeska szkoła filmowa (1963-1968), [w:] Czechosłowacka Nowa Fala, s. 35 . 
Jak wskazuje Peter Hames, bezpośrednio po interwencji Układu Warszawskiego $\mathrm{w}$ czechosłowackim przemyśle filmowym nie zaszły widoczne zmiany ${ }^{46}$. Co prawda, już w 1969 roku szefem kinematografii CSRS został Jiří Purš, jednak dopiero w roku następnym rząd przeprowadził reorganizację, rozwiązując autonomiczne zespoły filmowe oraz rady scenariuszowe. Ponadto unieważniono plany produkcyjne i usunięto ze stanowisk dyrektorów studiów filmowych Barrandov i Koliba. Stopniowo zatrzymywano kolejne filmy, przerywając produkcje lub nie dopuszczając do dystrybucji ${ }^{47}$. „Wiele filmów postanowiono «zamilczeć na zawsze»” - jak to ujął Mariusz Szczygieł, który do sygnalizowanej problematyki powracał nieraz w konwencji reportażowej ${ }^{48}$. Odnosząc się do zjazdu Komunistycznej Partii Czechosłowacji w 1971 roku, na którym ogłoszono „pokonanie chaosu" i potępiono tzw. absolutną swobodę twórczości, napisał:

To przemawiał prezydent republiki. - Przez te dwa lata - powiedział - Komitet Centralny pod przewodnictwem towarzysza Husáka wykonał dzieło godne szacunku. W imieniu artystów odetchnęła na mównicy aktorka Jiřina Švorcová, ekspedientka w serialu Kobieta za ladą: - Nareszcie! - Wrogowie socjalizmu - mówiła dalej - rozpętali w 1968 roku problem tak zwanej absolutnej swobody twórczości artystycznej. Popierani aplauzem Zachodu, zaczęli w końcu wzbudzać w ludziach niewiarę w socjalizm jako podstawową zasadę życia ${ }^{49}$.

W efekcie zaistniałych przeobrażeń kino czechosłowackie dekady lat 70. XX wieku rozwijało się pod dyktando nowej ekipy Gustáva Husáka, zorientowanej pod względem programowym na „kult przeszłości” i popularyzowanie tematyki II wojny światowej i pierwszych lat powojennych $^{50}$.

W okresie normalizacji - pisze Ewa Ciszewska - kino, jako element potencjalnie wywrotowy, a jednocześnie zdolny pełnić doniosłe funkcje ideologiczne, znalazło się pod baczną kuratelą. Logicznym następstwem nowej polityki kulturalnej stała się zmiana

${ }^{46}$ Peter Hames, Czechosłowacka Nowa Fala, tłum. Grażyna Świętochowska i in., Wydawnictwo słowo/obraz terytoria, Gdańsk 2009, s. 302.

47 Szerzej Ewa Ciszewska, Filmy nie do końca "normalne”..., s. 63; Peter Hames, Czechosłowacka Nowa Fala..., s. 302-303; tenże, Czechoslovakia: After the Spring, [w:] Post New Wave Cinema in the Soviet Union and Eastern Europe, red. Daniel J. Goulding, Indiana University Press, Bloomington, Indianapolis 1989, s. 107.

${ }^{48}$ Mariusz Szczygiel, Czeski film - nikt nic nie wie, a to Kafka, http://wyborcza. pl/1,75410,8956396,Czeski_film__nikt_nic_nie_wie_a_to_Kafka.html?disableRedirects=true (dostęp: 3.04.2018).

${ }^{49}$ Mariusz Szczygieł, Gottland, Wydawnictwo Czarne, Wołowiec 2010, s. 129.

${ }^{50}$ Peter Hames, Czechostowacka Nowa Fala..., s. 305; tenże, Czechoslovakia..., s. 107. 
profilu kinematografii: dramaty społeczne, satyry czy alegoryczne opowieści ustąpiły miejsca bądź socjalistycznym agitkom, bądź filmom uznawanym za niegroźne pod względem ideologicznym ${ }^{51}$.

Przyjęcie takiej a nie innej strategii spowodowało daleko idące komplikacje w czechosłowackim przemyśle filmowym. Przejawem trudności była m.in. niedostateczna liczba reżyserów i scenarzystów. Niektórzy, jak np. Věra Chytilová i Ester Krumbachová, zostali pozbawieni prawa wykonywania zawodu, a inni, jak Evald Schorm, ze względów ideologicznych i politycznych nie wyrażali chęci pracy ${ }^{52}$. Z jednej strony wielu twórców, a wśród nich m.in. Miloš Forman i Ivan Passer, zdecydowało się na emigrację $e^{53}$. Z drugiej zaś, aby utrzymać pracę, część reżyserów postanowiła albo reprezentować nową linię partii (np. Jaroslav Balík, Antonín Kachlík), albo realizować filmy, zachowując polityczną neutralność (np. Karel Kachyňa, Jiří Menzel) ${ }^{54}$. Opisane zmiany personalne wpłynęły niekorzystnie na estetyczną i techniczną wartość filmów produkowanych na początku lat 70. XX wieku i z tego powodu wielu nowofalowych reżyserów, m.in. Antonína Mášę, Hynka Bočana, Jiř́íego Menzla przywrócono z czasem do pracy $^{55}$. Zdaniem tego ostatniego, zasadniczym pozaartystycznym skutkiem interwencji 1968 roku były zmiany natury etycznej:

Wielu ludzi załamało się i doszło do wniosku - czego ja jestem przykładem - że świat nie jest tak idealny, jak go postrzegaliśmy, co więcej, że ludzie nie są tak dobrzy, jak nam się wydawało [...] właśnie w tamtych socrealistycznych czasach odkryłem, że takie myślenie to ułuda, że są też i tacy, u których podobnych wartości na pewno nie odnajdziemy. Było to dla mnie gorzkim przeżyciem. Sporo ludzi straciło robotę. Czego nie uczynili naziści, wykonała komuna [...]. Ludzie stracili wiarę $\mathrm{w}$ to, co robią. Gwałtownie nastąpił spadek jakości filmu, następnie jakości pracy samych twórców ${ }^{56}$.

Współpracę filmową utrudniał także fakt, że kinematografię CSRS charakteryzowała $\mathrm{w}$ tamtych latach niechęć kierownictwa programowego do

51 Ewa Ciszewska, Filmy nie do końca ",normalne”..., s. 64-65.

${ }^{52}$ Szerzej na ten temat pisze m.in. Dobrochna Dabert, Fenomen Czechosłowackiej Nowej Fali, s. 26-27.

${ }^{53}$ Szerzej Peter Hames, Czechostowacka Nowa Fala..., s. 306-307; Dorota Skotarczak, Czeska szkoła filmowa..., s. 35.

54 Szerzej Ewa Ciszewska, Filmy nie do końca "normalne"..., s. 64.

55 Peter Hames, Czechosłowacka Nowa Fala..., s. 307, 324.

${ }^{56}$ Filmowcy o Nowej Fali. Jiř́ Menzel, reżyser, [w:] Czechosłowacka Nowa Fala..., s. 82-83. 
tzw. tematów trudnych i eksperymentów twórczych ${ }^{57}$. Powyższa konstatacja zaczerpnięta ze sprawozdania polskiego NZK znajduje potwierdzenie w ustaleniach Petera Hamesa, który napisał, że: „Charakter prawie wszystkich filmów powstałych w latach siedemdziesiątych określa brak pomysłów na etapie scenariusza - strach przed ideologicznym nonkonformizmem skutkował tym, że filmy mówiły właściwie o niczym" ${ }^{\prime 58}$. Minister kultury i sztuki PRL z lat 1974-1978 Józef Tejchma określił zaistniałą wówczas w CSRS sytuację jako „pustynię kulturalną" o źródłach ideologicznych, będącą skutkiem interwencji. W kwietniu 1976 roku Tejchma w swoim dzienniku zanotował, że w Czechosłowacji „po 1968 roku nie ma twórczości filmowej” ${ }^{59}$.

Zdaniem strony polskiej opisane trudności wpływały na rozmiar i charakter współpracy w zakresie koprodukcji oraz eksportu i importu filmów ${ }^{60}$.

Koprodukcje i usługi techniczno-produkcyjne stanowiły bardzo ważną formę międzypaństwowej współpracy filmowej. Jak podkreśla Edward Zajiček:

Doświadczenia ze współpracy z krajami socjalistycznymi potwierdziły, że koprodukcja oraz świadczenie usług techniczno-produkcyjnych są korzystne dla uczestniczących stron. W przypadku kooperacji z krajami RWPG poza takimi korzyściami, jak zwiększenie atrakcyjności filmu koprodukcyjnego, rozłożenie jego kosztów na współpartnerów oraz wymiany doświadczeń technicznych i organizacyjnych, realizacja wspólnego filmu lub współpraca produkcyjna sprzyja wzajemnemu lepszemu poznaniu się i wymianie myśli oraz służy prezentacji kultury bratnich krajów i przyczynia się do pogłębienia integracji oraz więzów przyjaźni ${ }^{61}$.

Pomimo trudności i niedostatków koprodukcyjnych - we współpracy z NRD Czechosłowacja nakręciła trzykrotnie więcej filmów ${ }^{62}, z$ omawianej dekady pochodzi jeden z najciekawszych efektów umowy koproducenckiej z krajami socjalistycznymi - ekranizacja powieści Henryka Worcella pt. Zaklęte rewiry. Film o tym samym tytule wyreżyserował w 1975 roku

57 AAN, NZK, sygn. 2/185, Współpraca polsko-czechosłowacka w dziedzinie kinematografii w latach 1972-1973.

58 Peter Hames, Czechosłowacka Nowa Fala..., s. 306.

59 Józef Tejchma, Kulisy dymisji. Z dzienników ministra kultury 1974-1977, Oficyna Cracovia, Kraków 1991, s. 39, 202.

${ }^{60}$ AAN, NZK, sygn. 2/185, Współpraca polsko-czechosłowacka w dziedzinie kinematografii w latach 1972-1973.

${ }^{61}$ Edward Zajiček, Film polski. Ekonomika..., s. 100.

62 Szerzej na ten temat: Pavel Skopal, The Pragmatic Alliance of DEFA and Barrandov: Cultural Transfer, Popular Cinema and Czechoslovak-East German Co-productions, 1957-85, „Historical Journal of Film, Radio and Television” 2018, t. 38, s. 7. 
Janusz Majewski wespół z czechosłowackim Studiem Filmowym Barrandov. Pierwotnie Majewski planował kręcić film w Budapeszcie, ostatecznie wybrał jednak Pragę, gdzie zrealizowano większość zdjęć ${ }^{63}$. Początki współpracy ze scenarzystą Pavlem Hajným i czeskim studiem reżyser wspomina następująco:

Prawdę mówiąc, nie pamiętam, jak doszło do pierwszego spotkania, ale wiem, że bardzo szybko nawiązaliśmy kontakt [...]. Daliśmy mu do przeczytania książkę i on szybko zdeklarował się, że napisze scenariusz, a tymczasem Zespół Tor nawiązał odpowiednie kontakty z jego skupinou. Umowa o koprodukcji przewidywała, że wkłady obu stron będą mniej więcej proporcjonalne: pierwowzór literacki polski - scenarzysta Czech, reżyser Polak (ja) - operator Czech, scenograf Polski - kostiumograf czeski i tak dalej. Tak samo miejsca realizacji: trochę u nas, trochę tam ${ }^{64}$.

Zaklęte rewiry w okresie promowania dzieła bezpośrednio po premierze, która miała miejsce 27 listopada 1975 roku, zebrały wiele pochlebnych recenzji ${ }^{65}$ oraz nagród na polskich i zagranicznych festiwalach filmowych, m.in. w Gdańsku (nagroda za pierwszoplanową rolę męską na Festiwalu Polskich Filmów Fabularnych dla Romana Wilhelmiego) i Panamie, gdzie jury uhonorowało film aż trzykrotnie, wyróżniając reżysera Janusza Majewskiego, scenarzystę Pavla Hajnego oraz odtwórcę głównej roli Marka Kondrata.

Widziane po latach Zaklęte rewiry cały czas cieszą się przychylnością widowni, krytyków, a także historyków kina, którzy, jak Tadeusz Lubelski, dziś interpretują ten film jako zapowiedź Kina Moralnego Niepokoju. Oto, w jakich słowach opisuje go Lubelski:

[...] następny film Majewskiego, zapewne najważniejszy w jego dorobku, Zaklęte rewiry (1975) według powieści Henryka Worcella z 1936 roku, wykraczał poza konwencje mody retro. Co prawda i w nim odtworzenie klimatu lat trzydziestych, kiedy toczy się akcja, odgrywa ogromną rolę, dla tego celu film nakręcony został w Czechosłowacji (prototypowy Grand Hotel w Krakowie w peerelowskim stanie nie spełniał już wymagań), a magiczny wizerunek sali restauracyjnej oglądany zachwyconym wzrokiem głównego bohatera, sfotografowany przez Miroslava Ondříčka w restauracji Obecni Dum w Pradze, stanowił najbardziej zapadający w pamięć obraz filmu (na jego tle pojawiły się napisy czołówki) $[\ldots]^{66}$.

${ }^{63}$ Szerzej na temat filmu zob. Stanisław Zawiśliński, Ach, te rewiry..., „Magazyn Filmowy SFP" 2015, nr 51, s. 76, a także film dokumentalny Grzegorza Jankowskiego i Jacka Szczerby pt. Já mám hlad... o "Zaklętych rewirach" Janusza Majewskiego (1999).

${ }^{64}$ Janusz Majewski, Ostatni klaps. Pamiętnik moich filmów, Wydawnictwo Autorskie, Warszawa 2006, s. 182.

${ }^{65}$ Zob. np. Wanda Wertenstein, Zaklęte rewiry - sekrety madrej precyzji, „Kino” 1975, nr 11.

${ }^{66}$ Tadeusz Lubelski, Historia kina polskiego 1895-2014, Universitas, Kraków 2015, s. 387. 
Z kolei sam reżyser o omawianym dziele napisał: „Jest i chyba pozostanie moim najlepszym filmem" ${ }^{\prime 67}$. Dzięki specjalnemu zaproszeniu Museum of Modern Art w Nowym Jorku możliwość jego obejrzenia otrzymała również publiczność w Stanach Zjednoczonych. Amerykański pokaz Zaklętych rewirów z 1977 roku spotkał się z ciepłym przyjęciem i dużym zainteresowaniem ${ }^{68}$.

Zaklęte rewiry to nie jest jedyne wspólne przedsięwzięcie PRL i CSRS z dekady gierkowskiej. W 1976 roku powstał dramat sensacyjny pt. Krótkie życie na podstawie opowiadania Stanisława Wałacha. Film oparty na scenariuszu Aleksandra Rowińskiego wyreżyserował Zbigniew Kuźmiński. Krótkie życie wyprodukował Zespół Filmowy Pryzmat wraz ze słowacką Wytwórnią Filmową Koliba ${ }^{69}$. Warto w tym miejscu dodać, że generalnie we współpracy z południowym sąsiadem stawiano na rozwój kontaktów ze środowiskiem słowackim, które wydawało się bardziej przychylne kinematografii PRL, o czym w dużej mierze decydował fakt, że tamtejszy rynek filmowy podlegał mniejszym ograniczeniom ${ }^{70}$. Usługi produkcyjne przy innym filmie Kuźmińskiego - Sto koni do stu brzegów (1978) świadczyło z kolei Studio Filmowe Barrandov. Ponadto we współpracy z czeskim producentem, ale też kinematografiami innych europejskich krajów socjalistycznych, Polska zrealizowała film pt. Żołnierze wolności (1977, reż. Jurij Ozierow) ${ }^{71}$.

Nie wszystkie plany dotyczące wspólnej realizacji filmów fabularnych udało się $\mathrm{w}$ omawianej dekadzie zrealizowaćn ${ }^{72}$. Jak wynika z dokumentów archiwalnych, w 1972 i 1973 roku obie strony rozważały działania koprodukcyjne. Strona czeska zaproponowała realizację dwóch komedii: o czechosłowackich marynarzach w Trójmieście i polskich robotnikach w Czechosłowacji. Wraz z kinematografią CSRS planowano ponadto przeniesienie na srebrny ekran scenariuszy Andrzeja Twerdochliba (Długi cień) oraz Pavla Hajnego (Zmory). Wspólne zamierzenia realizacyjne oraz potrzebę dalszych rozmów z koproducentem słowackim sygnalizował również Aleksander Ścibor-Rylski na naradzie Zespołów Filmowych w 1975 roku:

Mamy też propozycję koprodukcji polsko-słowackiej - informował - scenariusz jest gotowy, ale nie mamy jeszcze zgody oficjalnej [...] jeśli nie napotkalibyśmy na przeszko$\mathrm{dy}$, to film mógłby być realizowany w tym roku i towarowo oddany też $\mathrm{w}$ tym roku ${ }^{73}$.

${ }^{67}$ Janusz Majewski, Ostatni klaps..., s. 202.

68 Tamże, s. 204.

69 Szerzej na temat filmu pisze w niniejszym tomie Jarosław Grzechowiak.

${ }^{70}$ Joanna Szczutkowska, Polityka kulturalna..., s. 309; Peter Hames, Czechoslovakia..., s. 114.

${ }^{71}$ Szerzej na temat filmu: Mieczysław Wojtczak, Kronika nie tylko filmowa, Wydawnictwo Studio Emka, Warszawa 2004, s. 133-138.

${ }^{72}$ Joanna Szczutkowska, Polityka kulturalna..., s. 306.

${ }^{73}$ Cyt. za: tamże. 
Z przywołanych wyżej względów Czechosłowacji bardziej niż na wspólnej realizacji filmów zależało na usługach artystycznych polskich reżyserów i aktorów. Starano się w ten sposób wpłynąć w jakiś sposób na własne środowisko filmowe. Niektóre propozycje polscy twórcy przyjmowali, na inne nie chcieli się zgodzić, uważając, że Czechosłowacy powinni swoje problemy rozwiązywać bez pomocy z zewnątrz ${ }^{74}$. W ramach wymiany usług filmowych angażowano aktorów. Wymiana aktorska Polski z Czechosłowacją przybierała kilka zasadniczych form, obejmując występy w rolach pierwszoplanowych i epizodach w filmach współprodukowanych oraz występy w filmach realizowanych za granicą bez umów współprodukcyjnych lub w ramach świadczenia usług przez stronę polską ${ }^{75}$. W tym kontekście warto przywołać czechosłowackie filmy Barbary Brylskiej, zresztą chętnie angażowanej w latach 70. XX wieku przez reżyserów także innych państw tzw. obozu socjalistycznego: Koncert pre pozostalých (1976, reż. Dušan Trančík) i Tichý Američan v Praze (1977, reż. Josef Mach, Štěpán Skalský). Ponadto zgodnie z art. 2 umowy z 1966 roku współpraca kulturalna PRLCSRS miała być prowadzona przez „przyjmowanie obywateli drugiej Umawiającej się strony na studia, staż lub praktykę"776. Do postanowień tych stosowano się, czego w dziedzinie kinematografii najlepszą egzemplifikacją pozostanie prawdopodobnie „czeska edukacja” Agnieszki Holland, absolwentki Praskiej Szkoły Filmowej FAMU (1971). Czeskie inspiracje i wpływy są bardzo widoczne w twórczości reżyserki ${ }^{77}$, która w rozmowie z Marią Kornatowską odniosła się także do wpływu wydarzeń 1968 roku na jej stosunki z Czechosłowakami i aktywność polityczną:

Po interwencji, ponieważ Polacy brali w niej udział, zrobiłam się bardziej aktywna politycznie, chciałam w ten sposób odkupić nasze winy. Napytałam sobie wtedy różnych kłopotów, ale w sumie koledzy mieli do mnie zaufanie. Nie odczuwałam ostracyzmu ani oskarżeń z ich strony ${ }^{78}$.

Odnosząc się do kwestii importu i eksportu, o ile liczba sprowadzanych do Polski filmów po 1968 roku w zasadzie się nie zmieniła, to z po-

74 AAN, NZK, sygn. 2/185, Współpraca polsko-czechosłowacka w dziedzinie kinematografii w latach 1972-1973.

${ }^{75}$ Janina Połęcka, Oskar Sobański, Czy i jak stworzyć wspólny rynek aktorski socjalistycznych kinematografii?, „Kino” 1971, nr 7, s. 41.

${ }^{76}$ Dz. U. 1966 r. nr 32, poz. 190.

77 Szerzej na ten temat: Mariola Jankun-Dopartowa, Gorzkie kino Agnieszki Holland, Wydawnictwo słowo/obraz terytoria, Gdańsk 2000, s. 81-106.

${ }^{78}$ Agnieszka Holland, Magia i pieniadze. Rozmowy przeprowadziła Maria Kornatowska, Wydawnictwo Znak, Kraków 2002, s. 115. 
wodu ostrożnej polityki komisji kwalifikacyjnych CSRS zakupy polskich filmów fabularnych uległy wyraźnemu zmniejszeniu. W opracowaniu NZK zanotowano:

\begin{abstract}
Wszelki eksperyment artystyczno-formalny, jak też problemowe, dyskusyjne stawianie spraw płoszy czechosłowackich rozpowszechniaczy, którzy wyczuleni są na ewentualne elementy krytykanctwa lub maniery twórczej importowanej z Zachodu. $\mathrm{W}$ rezultacie najłatwiej przez to przeczulone sito selekcji przechodzą słabe, ale poprawne ideowo filmy i filmy neutralne politycznie. W wyniku tego czechosłowackie zakupy polskich filmów fabularnych są mniejsze i w zestawie mniej atrakcyjne, prezentujące widzowi czeskiemu mniej niż przeciętny poziom artystyczny polskiej produkcji filmowej. Ma to oczywiście negatywny wpływ na wyniki rozpowszechniania filmów polskich na terenie Czechosłowacji ${ }^{79}$.
\end{abstract}

Zdaniem Tadeusza Miczki owa specyficzna polityka selekcji nie zniechęciła tamtejszych widzów, którzy wykazywali więcej zainteresowania polskim kinem niż Polacy kinem CSRS (szczególną popularnością w CSRS cieszył się Potop Jerzego Hoffmana ${ }^{80}$ ), mimo iż otrzymywali jego zniekształcony obraz, nieuwzględniający np. najważniejszych dzieł Kina Moralnego Niepokoju ${ }^{81}$. Jeśli zaś chodzi o recepcję filmów czechosłowackich w Polsce, generalnie, powtórzyć należy za Ewą Ciszewską, okres tzw. normalizacji zapisał się $\mathrm{w}$ historii kinematografii czechosłowackiej bardzo pozytywnie pod względem liczby produkowanych rocznie filmów (ok. 40) i efektów eksportowych - zagraniczne sukcesy frekwencyjne odnosiły zwłaszcza filmy dla dzieci i młodzieży, komedie, filmy kryminalne i seriale ${ }^{82}$. Potwierdzenie przynoszą nie tylko oficjalne źródła pisane, lecz także pamięć społeczna - po dziś dzień wspomina się w Polsce choćby popularne onegdaj seriale telewizyjne Kobieta za lada (Žena za pultem, reż. Jaroslav Dudek, 1977) czy Szpital na peryferiach (Nemocnice na kraji města, reż. Jaroslav Dudek, 1977-1981). Statystycznie, w latach 1971-1976 na ekranach polskich kin wyświetlono 70 czechosłowackich filmów fabularnych, m.in.: Dni zdrady (Dni zrady I-II, reż. Otakar Vávra, 1973), I znów skacze przez katuże... (Už zase skáču přes kaluže, reż. Karel Kachyňa, 1970), Kochankowie roku pierwszego (Milenci v roce jedna, reż. Jaroslav Balík, 1974), O miłości (Láska, reż. Karel Kachyňa, 1973), ... i pozdrawiam jaskótki (... a pozdravuji vlaštovky, reż. Jaromil Jireš, 1972), Lampy naftowe (Petrolejové lampy,

79 AAN, NZK, sygn. 2/185, Współpraca polsko-czechosłowacka w dziedzinie kinematografii w latach 1972-1973.

${ }^{80}$ Bogusław Płaza, Kultura zbliża narody..., s. 121.

81 Tadeusz Miczka, Kino czeskie w Polsce i kino polskie w Czechosłowacji..., s. 266.

82 Ewa Ciszewska, Filmy nie do końca „normalne"..., s. 65. 


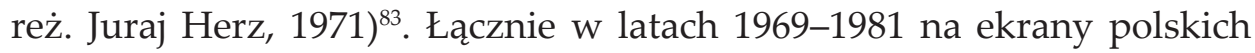
wprowadzono 166 filmów południowych sąsiadów ${ }^{84}$. Niektóre filmy problemowe, np. Katarzyna i jej córki (Kateřina a její děti, reż. Václav Gajer, 1970) i Nie chcę nic styszeć (Nechci nic slyšet, reż. Ota Koval, 1978) trafiały do tzw. puli specjalnej kin studyjnych i dyskusyjnych klubów filmowych (DKF). Nie rozpowszechniano jednak propagandowych dramatów politycznych, komentujących zdarzenia 1968 roku $^{85}$. Od drugiej połowy lat 70. XX wieku, dzięki rozmaitym przeglądom i konferencjom, prezentowano nowofalowe dzieła Czechosłowaków, które, odmiennie niż twórczość okresu "normalizacji”, były wdzięcznym przedmiotem analiz Pola$k^{\prime} w^{86}$. Duży wkład w tym zakresie miały inicjatywy rozkwitających w tej dekadzie DKF-ów. Ich działalność sprzyjała popularyzacji „bratnich” kinematografii. Przykładowo, DKF „Rumcajs” w Częstochowie, współpracujący z Ośrodkiem Kultury i Informacji CSRS w Warszawie, każdego roku organizował przeglądy filmów czechosłowackich oraz spotkania z twórcami czy przedstawicielami Stowarzyszenia Filmowców CSRS ${ }^{87}$. Bezpośrednie kontakty z klubami filmowymi w Czechosłowacji utrzymywał gliwicki DKF "Iksik”, zapraszając ich przedstawicieli (z Ostrawy) do udziału w seminariach filmowych na terenie Polski (np. w Wiśle). W zamian delegatów polskich klubów podejmowali organizatorzy podobnych imprez na terenie CSRS. Dzięki współpracy z klubem filmowym w Ostrawie przedstawiciele „Iksika” mogli brać udział w corocznym Ogólnokrajowym Seminarium klubów czeskich w Pisku, zyskując tym samym szansę zapoznania się z formami i warunkami działalności klubów filmowych w Czechosłowacji ${ }^{88}$.

Większych trudności we współpracy polsko-czechosłowackiej nie odnotowano $\mathrm{w}$ zakresie organizacji i uczestnictwa $\mathrm{w}$ imprezach i festiwalach filmowych, m.in. w Karlowych Warach, Krakowie czy Przeglądzie Filmów Swiata - „Konfrontacje”, odgrywających w zagranicznej polityce filmowej krajów socjalistycznych istotną rolę informacyjno-propagandową i handlową. Zgodnie z założeniami organizowano uroczyste premiery, pokazy i przeglądy. Przykładowo w 1972 roku odbyła się w Czechosłowacji uroczysta premiera Perty w koronie (1971, reż. Kazimierz

\footnotetext{
${ }^{83}$ Bogusław Płaza, Kultura zbliża narody..., s. 121.

${ }^{84}$ Tadeusz Miczka, Kino czeskie w Polsce $i$ kino polskie w Czechosłowacji, s. 265.

85 Tamże, s. 266.

86 Tamże.

87 Jacek Tomczyk, To już 22 lata..., „Film na Świecie” 1978, nr 6, s. 115.

${ }^{88}$ Bogdan Moździerz, Kluby w Czechosłowacji (ruch klubowy w świecie), „Kultura Filmowa" 1973, nr 1, s. 103.
} 
Kutz), zaś w Polsce Ślubu bez obraczki (Svatba bez prstýnku, reż. Vladimír Čech, 1972). Kolejny rok rozwoju stosunków filmowych upłynął pod znakiem pięćsetnej rocznicy urodzin Mikołaja Kopernika i 25. rocznicy Rewolucji Lutowej w CSRS. Zadecydowano o tym na styczniowym spotkaniu w Warszawie wiceministra kultury i sztuki Czesława Wiśniewskiego i zastępcy dyrektora generalnego Czechosłowackiego Filmu Bohumila Steinera. Pamięć o przewrocie lutowym była zresztą niejednokrotnie okazją do organizowania w Polsce specjalnych pokazów filmowych, jak ten w 1978 roku, kiedy w warszawskim kinie „Bajka” wyświetlono Zwycięski lud (Vítězný líd, reż. Vojtěch Trapl, 1977) ${ }^{89}$. Dnia 5 maja 1980 roku z okazji święta narodowego CSRS w tym samym miejscu odbyła się uroczysta premiera Tajemnicy stalowego miasta (Tajemství ocelového města, reż. Ludvík Ráža, 1978) z udziałem filmowców. W skład delegacji CSRS weszli: scenarzysta, kierownik literacki wytwórni filmowej Gottwaldov Josef Vaculík, montażysta Maximilián Remeň oraz aktorki Bohumila Myslíková i Milada Svobodová. Czechosłowaccy filmowcy uczestniczyli także w Przeglądzie Filmów Czechosłowackich w Szczecinie i Katowicach, który odbył się w dniach od 7 do 17 maja. W programie przeglądu znalazły się m.in. następujące filmy: Boska Emma (Božská Ema, reż. Jiří Krejčík, 1979), Ja już będę grzeczny, dziadku (Já už budu hodný, dědečku!, reż. Petr Schulhoff, 1978) oraz Solo dla starszej pani (Sólo pro starou dámu, reż. Václav Matějka, 1978)90.

Kinematografie obu krajów reprezentowano i nagradzano na międzynarodowych festiwalach filmowych organizowanych w Czechosłowacji i w Polsce. Polskie filmy zdobyły w omawianym czasie wiele wyróżnień na MFF w Karlowych Warach: w 1972 roku Nagrodę Główną (jedną z czterech równorzędnych) otrzymał Poślizg (1972, reż. Jan Łomnicki), w 1974 roku Nagrodą Specjalną Jury wyróżniono film Ciemna rzeka (1973, reż. Sylwester Szyszko), w 1976 roku nagrodą za kreację męską dla Zygmunta Malanowicza wyróżniono Jarosława Dąbrowskiego (1975, reż. Bohdan Poręba). W 1980 roku nagrodę w konkursie debiutów przyznano Olimpiadzie '40 (1980, reż. Andrzej Kotkowski). W tym samym roku Nagrodę Specjalną Jury wręczono Kazimierzowi Kutzowi za Paciorki jednego różańca (1979). Wiele polskich filmów fabularnych wyróżniono na Międzynarodowym Festiwalu Filmów Telewizyjnych w Pradze. W latach 70. XX wieku nagrody zdobyły: Przez dziewięć mostów (1971, reż. Ryszard Ber), Chłopcy (1971, reż. Ryszard Ber), Jutro (1973, reż. Bogdan Hussakowski). Polskie filmy zdobywały także nagrody na specjalistycznych

89 Joanna Szczutkowska, Polityka kulturalna..., s. 309.

90 Kronika, „Filmowy Serwis Prasowy” 1980, nr 12, s. 19. 
festiwalach filmowych: MFF Turystycznych „Tourfilm” w Szpindlerowym Młynie, MFF Naukowych „Techfilm '75” w Pardubicach, MFF „Ecofilm" w Pardubicach. W 1978 roku Nagrodą Specjalną za reżyserię na MFF Ludzi Pracy w Libercu przyznano Jerzemu Kawalerowiczowi za Śmierć prezydenta (1977). Filmy dokumentalne $W$ słońcu (1971, reż. Zygmunt Koziarski) oraz Żołnierz godziny nie wybiera (1971, reż. Donat Czerewacz) wyróżniono z kolei na MFF Armii Państw Układu Warszawskiego w Brnie ${ }^{91}$. Kinematografia CSRS obecna była w latach 70. na festiwalach filmowych w Polsce. Czechosłowackie filmy krótkometrażowe: Kasiarz (Kasař, reż. Jaromil Jireš, 1974), Nie fantazjuj (Nesmysl, reż. Adolf Born, Jaroslav Doubrava, Miloš Macourek, 1975), Podwójne życie Józefa Hlinomaze (Dvojí život Josefa Hlinomaze, reż. Jiří Brdečka, 1976), Drabina (Rebrík, reż. Viktor Kubal, 1978), Szczęście z Kokury (Štěstí z Kokury, reż. Bohumil Musil, 1979) zdobywały nagrody na Międzynarodowym Festiwalu Filmów Krótkometrażowych w Krakowie ${ }^{92}$.

Ponadto Polska i Czechosłowacja współpracowały przy organizacji międzynarodowych festiwali twórczości amatorskiej krajów socjalistycznych. Jedna z tego typu imprez odbyła się w dniach 2-8 maja 1980 roku w Świeradowie-Zdroju z okazji 35. rocznicy „zwycięstwa nad faszyzmem". W ramach festiwalu każdy kraj przedstawił program filmowy, któremu towarzyszyło seminarium na temat roli scenariusza $\mathrm{w}$ filmie amatorskim $^{93}$.

Osobnym rozdziałem $\mathrm{w}$ dziejach międzypaństwowych związków filmowych jest działalność ośrodków kulturalno-informacyjnych Polski w Pradze i Bratysławie i Czechosłowacji w Warszawie, działających na podstawie protokołu podpisanego w Warszawie 27 marca 1958 roku $^{94}$. Celem ich funkcjonowania miało być lepsze wzajemne poznanie Polaków, Czechów i Słowaków, czemu służyła m.in. propaganda audiowizualna ${ }^{95}$. Interwencja wojsk Układu Warszawskiego w 1968 roku utrudniła działania polskich ośrodków kultury, starających się w kolejnej dekadzie kontynuować dotychczasowe formy pracy ${ }^{96}$. Przy udziale tych instytucji organizowano Dni Kultury Polskiej w Czechosłowacji i Dni Kultury

${ }^{91}$ Małgorzata Hendrykowska, Kronika kinematografii polskiej 1895-1997, Ars Nova, Poznań 1999, s. 305, 313, 320, 329, 337, 343, 351, 359, 367, 374. Zob. też: Bogusław Płaza, Kultura zbliża narody..., s. 121-122.

${ }^{92}$ Dane z: http://www.krakowfilmfestival.pl/archiwum (dostęp: 20.05.2017).

${ }^{93}$ Kronika, "Filmowy Serwis Prasowy” 1980, nr 12, s. 19.

${ }^{94}$ Janina Bilińska, Stosunki między Polska a Czechosłowacja, s. 76.

95 Anna Szczepańska, Warszawa-Praga..., s. 479, 481.

96 Tamże, s. 491-492. 
Czechosłowackiej w Polsce, którym towarzyszyły pokazy filmowe ${ }^{97}$. Ważnym wydarzeniem w kontekście popularyzowania twórczości obu krajów były "dni" i „tygodnie” filmów. Przykładowo, z okazji 30-lecia PRL w Czechach i Słowacji zorganizowano Tydzień Filmów Polskich połączony z przeglądem filmów krótkometrażowych ${ }^{98}$. W Ośrodku Kultury Czechosłowackiej w Warszawie organizowano rozmaite wydarzenia artystyczne, m.in. pokazy filmowe z okazji świąt narodowych. Dla przykładu, 27 sierpnia 1971 roku, z okazji 27. rocznicy wybuchu słowackiego powstania narodowego zorganizowano pokaz filmów na temat jego historii, a także aktualnego życia Słowacji ${ }^{99}$.

Film i kinematografia to dziedzina, która dość szybko połączyła Polskę i Czechosłowację po II wojnie światowej, poszerzając wydatnie sąsiedzkie dziedzictwo kulturowe. Jednakże w dziejach związków filmowych tych krajów okresy rozwoju i poszukiwań nowych formuł przeplatają się z momentami załamania kooperacji na tle napięć politycznych w 1956 i 1968 roku. Dekada lat 70. XX wieku, obejmująca lata tzw. normalizacji w CSRS, przyniosła poprawę oficjalnych stosunków, lecz - jak zauważa Anna Szczepańska - na „prawdziwie dobre relacje, trzeba było czekać do 1989 r." ${ }^{\prime 100}$. Współpraca filmowa PRL-CSRS w tzw. dekadzie gierkowskiej pomimo wielu trudności (także tych wykraczających poza oficjalną politykę, związanych przez cały okres uzależnienia od ZSRR z brakiem chęci lepszego wzajemnego poznania się Polaków, Czechów i Słowaków ${ }^{101}$, a nadto np. ograniczeniami materialnymi ${ }^{102}$ ) rozwijała się, zapisując się w dziejach wielowiekowych kontaktów kulturalnych jako osobny wielowątkowy rozdział, co starano się wykazać w niniejszym artykule. Przyjęcie w tekście perspektywy oficjalnej nie oddaje siłą rzeczy złożoności ówczesnych relacji, traktując powierzchownie takie kwestie, jak np. odczucia widowni czy niezwykle ważną sferę kontaktów społecznych;

97 Bogusław Płaza, Kultura zbliża narody..., s. 119, 121.

98 AAN, NZK, sygn. 1/104, Program imprez filmowych organizowanych w roku 1974 za granicą z okazji XXX-lecia PRL.

99 Kronika wydarzeń, „Filmowy Serwis Prasowy” 1971, nr 19, s. 2.

100 Anna Szczepańska, Warszawa - Praga..., s. 504.

101 Zwraca na to uwagę m.in. Tadeusz Miczka, Kino czeskie w Polsce i kino polskie w Czechostowacji..., s. 245-246.

102 Zob. Magdalena Sirecka-Wołodko, Zagraniczna polityka kulturalna Polski..., s. 181. 
pozwala jednak uporządkować ich wielokierunkowośćcio3. Rozważania nie uwzględniają raportów placówek dyplomatycznych i konsularnych, stąd znikome informacje na temat propagandowej działalności narodowych ośrodków kultury w Pradze i Bratysławie oraz Warszawie, a także przygranicznej współpracy kulturalnej - poddane analizie będą dopełnieniem przedstawionego obrazu kontaktów dwustronnych.

\section{Bibliografia}

\section{Archiwalia}

Archiwum Akt Nowych - Naczelny Zarząd Kinematografii.

\section{Druki zwarte}

Biegański Zdzisław, Kino puli specjalnej: filmy jugosłowiańskie na ekranach kin Polski Ludowej, [w:] Polska i Jugostawia w stosunkach międzynarodowych po II wojnie światowej, red. Momcilo Pavlović, Andrzej Zaćmiński, Wydawnictwo Uniwersytetu Kazimierza Wielkiego, Bydgoszcz 2014.

Bilińska Janina, Stosunki między Polska a Czechosłowacja, [w:] Stosunki Polski z innymi państwami socjalistycznymi, red. Czesław Mojsiewicz, Państwowe Wydawnictwo Naukowe, Warszawa 1973.

Calvocoressi Peter, Polityka międzynarodowa 1945-2000, tłum. Wiesława Bolimowska-Garwacka, Hanna Burska, Stanisław Głąbiński, Janusz Gołębiowski, Książka i Wiedza, Warszawa 2002.

Dabert Dobrochna, Fenomen Czechostowackiej Nowej Fali, [w:] Czechosłowacka Nowa Fala, red. Marzena Matla, Lenka Németh Vítová, Instytut Historii UAM, Poznań 2012.

Dokumenty i materiały do historii stosunków polsko-czechosłowackich, t. I, cz. 2, red. Wiesław Balcerak, Zakład Narodowy im. Ossolińskich, Wrocław 1985.

${ }^{103} \mathrm{Na}$ fundamentalne znaczenie dokładnego rozpoznania oficjalnej wersji wzajemnych relacji PRL-CSRS wskazuje Tadeusz Miczka: „oficjalne stosunki między obydwoma państwami [...] tworzyły obraz polskiego kina w Czechosłowacji i czeskiego w Polsce [...]. Taki obraz ma przed sobą dzisiaj historyk badający proces przenikania się kultur na tym obszarze, obraz kreowany przez państwowe propagandy, które tworzyły statystyki i dokumenty [...] bardzo często unifikujące i zniekształcające prawdziwe, złożone odczucia widowni i wartości samych obrazów ekranowych. Oficjalna wersja historii tych przenikań musi jednak stanowić punkt wyjścia [...], ponieważ wyznaczała ona w rzeczywistości horyzont faktom, zdarzeniom i zjawiskom filmowym. Jego zasięg należy dokładnie rozpoznać, zanim przystąpi się do badania głębszych pokładów tych wzajemnych relacji" - Tadeusz Miczka, Kino czeskie w Polsce i kino polskie w Czechosłowacji..., s. 246. 
Eisler Jerzy, Siedmiu wspaniatych. Poczet pierwszych sekretarzy KC PZPR, Wydawnictwo Czerwone i Czarne, Warszawa 2014.

Filmowcy o Nowej Fali. Jiři Menzel, reżyser, [w:] Czechosłowacka Nowa Fala, red. Marzena Matla, Lenka Németh Vítová, Instytut Historii UAM, Poznań 2012.

Hames Peter, Czechosłowacka Nowa Fala, tłum. Grażyna Świętochowska i in., Wydawnictwo słowo/obraz terytoria, Gdańsk 2009.

Hames Peter, Czechoslovakia: After the Spring, [w:] Post New Wave Cinema in the Soviet Union and Eastern Europe, red. Daniel J. Goulding, Indiana University Press, Bloomington, Indianapolis 1989.

Hendrykowska Małgorzata, Kronika kinematografii polskiej 1895-1997, Ars Nova, Poznań 1999.

Holland Agnieszka, Magia i pieniadze. Rozmowy przeprowadziła Maria Kornatowska, Wydawnictwo Znak, Kraków 2002.

Homolka Zelinová Jana, Československo-polské kulturní styky 1945-1948, Uniwersytet Masaryka, Brno 2016.

Jankun-Dopartowa Mariola, Gorzkie kino Agnieszki Holland, Wydawnictwo słowo/obraz terytoria, Gdańsk 2000.

Kemp-Welch Anthony, Polska pod rządami komunistów 1944-1989, tłum. Joanna Gilewicz, Wydawnictwo Uniwersytetu Jagiellońskiego, Kraków 2008.

Lubelski Tadeusz, Historia kina polskiego 1895-2014, Universitas, Kraków 2015.

Majewski Janusz, Ostatni klaps. Pamiętnik moich filmów, Wydawnictwo Autorskie, Warszawa 2006.

Miczka Tadeusz, Kino czeskie w Polsce i kino polskie w Czechosłowacji w okresie realnego socjalizmu (1945-1989), [w:] Czechy i Polska na szlakach ich kulturalnego rozwoju, red. Jerzy Wyrozumski, Międzynarodowe Centrum Kultury, Kraków 1998.

Płaza Bogusław, Kultura zbliża narody. O wspótpracy kulturalnej Polski z zagranica w latach 1945-1976, Książka i Wiedza, Warszawa 1978.

Roszkowski Wojciech, Najnowsza historia Polski 1945-1980, Świat Książki, Warszawa 2003.

Rychlík Jan, Społeczeństwo czechosłowackie i Komunistyczna Partia Czechostowacji a wydarzenia w Polsce w latach 1980-1981, tłum. Manuela Maciołek, [w:] Między przymusowa przyjaźnia a prawdziwa solidarnościa. Czesi - Polacy - Słowacy 1938/39-1945-1989, red. Petr Blažek, Paweł Jaworski, Łukasz Kamiński, Instytut Pamięci Narodowej - Komisja Ścigania Zbrodni przeciwko Narodowi Polskiemu, Warszawa 2009.

Sirecka-Wołodko Magdalena, Zagraniczna polityka kulturalna Polski w latach 1956-1970, Wydawnictwo Mado, Torun 2011.

Skobelski Robert, Polityka PRL wobec państw socjalistycznych w latach 1956-1970. Wspótpraca - napięcia - konflikty, Wydawnictwo Poznańskie, Poznań 2010.

Skopal Pavel, Międzynarodowa konferencja jako instytucja dyscyplinująca. "Rewizjonistyczne tendencje" w polskim kinie lat 1957-1960 z perspektywy radzieckiej, tłum. Miłosz Stelmach, [w:] Kino polskie jako transnarodowe, red. Sebastian Jagielski, Magdalena Podsiadło, Universitas, Kraków 2017.

Skotarczak Dorota, Czeska szkoła filmowa (1963-1968), [w:] Czechosłowacka Nowa Fala, red. Marzena Matla, Lenka Németh Vítová, Instytut Historii UAM, Poznań 2012.

Skrzypek Andrzej, Dyplomatyczne dzieje PRL w latach 1956-1989, Akademia Humanistyczna im. A. Gieysztora, Oficyna Wydawnicza ASPRA-JR, Pułtusk-Warszawa 2010.

Skwara Janusz, Nowy film czechosłowacki, Wydawnictwo Artystyczne i Filmowe, Warszawa 1968.

Szczepańska Anna, Warszawa - Praga 1948-1968. Od nakazanej przyjaźni do kryzysu, Wydawnictwo Naukowe Uniwersytetu Szczecińskiego, Szczecin 2011. 
Szczutkowska Joanna, Polityka kulturalna PRL w dziedzinie kinematografii w latach 70., Wydawnictwo Uniwersytetu Kazimierza Wielkiego, Bydgoszcz 2014.

Szczutkowska Joanna, Wspótpraca kulturalna Polski z Jugosławia w dziedzinie kinematografii w latach siedemdziesiatych XX wieku, [w:] Polska i Jugostawia po II wojnie światowej, red. Momcilo Pavlović, Nebojsa Stambolija, Andrzej Zaćmiński, Wydawnictwo Uniwersytetu Kazimierza Wielkiego, Bydgoszcz 2016.

Szczygieł Mariusz, Gottland, Wydawnictwo Czarne, Wołowiec 2010.

Tejchma Józef, Kulisy dymisji. Z dzienników ministra kultury 1974-1977, Oficyna Cracovia, Kraków 1991.

Tronowicz Henryk, Film czechosłowacki w Polsce, Redakcja Wydawnictw Filmowych Przedsiębiorstwa Dystrybucji Filmów, Warszawa 1984.

Umowa o wspótpracy kulturalnej między Rządem Polskiej Rzeczypospolitej Ludowej a Rzadem Czechosłowackiej Republiki Socjalistycznej, podpisana w Warszawie dnia 22 stycznia 1966 r., Dz. U. 1966 r. nr 32, poz. 190.

Wojtczak Mieczysław, Kronika nie tylko filmowa, Wydawnictwo Studio Emka, Warszawa 2004.

Zając Justyna, Zięba Ryszard, Polska w stosunkach międzynarodowych 1945-1989, Wydawnictwo Adam Marszałek, Toruń 2005.

Zajiček Edward, Film polski. Ekonomika i organizacja produkcji, Państwowe Wydawnictwo Naukowe, Warszawa 1983.

\section{Czasopisma}

Ciszewska Ewa, Filmy nie do końca "normalne": z historii czechosłowackiej "normalizacji", „Kino” 2010, nr 10.

Ciszewska Ewa, Trudna sztuka koprodukcji. O pierwszym powojennym filmie polsko-czechostowackim „Zadzwońcie do mojej żony” (1958) Jaroslava Macha, „Kwartalnik Filmowy” 2016, nr 96.

Kronika, „Filmowy Serwis Prasowy” 1979, nr 4.

Kronika, „Filmowy Serwis Prasowy” 1980, nr 12.

Kronika wydarzeń, „Filmowy Serwis Prasowy” 1971, nr 19.

Moździerz Bogdan, Kluby w Czechosłowacji (ruch klubowy w świecie), „Kultura Filmowa” 1973, nr 1 .

Połęcka Janina, Sobański Oskar, Czy i jak stworzyć wspólny rynek aktorski socjalistycznych kinematografii?, „Kino” 1971, nr 7.

Purš Jiří, XXX lat kinematografii, „Kino” 1976, nr 1.

Skopal Pavel, The Pragmatic Alliance of DEFA and Barrandov: Cultural Transfer, Popular Cinema and Czechoslovak-East German Co-productions, 1957-85, „Historical Journal of Film, Radio and Television" 2018, t. 38.

Szczepańska-Dudziak Anna, Polsko-czechosłowackie kontakty kulturalne i naukowe 1945-1956, „Historia Slavorum Occidentis” 2015, nr 1.

Tomczyk Jacek, To już 22 lata..., „Film na Świecie” 1978, nr 6.

Wertenstein Wanda, Zaklęte rewiry - sekrety mąrej precyzji, „Kino” 1975, nr 11.

Zawiśliński Stanisław, Ach, te rewiry..., „Magazyn Filmowy SFP” 2015, nr 51. 
Kontakty filmowe...

\section{Źródła internetowe}

http://www.krakowfilmfestival.pl/archiwum (dostęp: 20.05.2017).

Szczygieł Mariusz, Czeski film - nikt nic nie wie, a to Kafka, http://wyborcza. pl/1,75410,8956396,Czeski_film__nikt_nic_nie_wie__a_to_Kafka.html?disableRedirects=true (dostęp: 3.04.2018).

\section{Streszczenie}

Film i kinematografia były dziedziną kultury i sztuki, która dość szybko połączyła Polskę i Czechosłowację po II wojnie światowej. Jednakże w dziejach związków filmowych tych krajów okresy rozwoju i poszukiwań nowych formuł przeplatają się z momentami załamania kooperacji na tle napięć politycznych (polski Październik 1956 roku, udział Polski w interwencji wojsk Układu Warszawskiego i stłumienie Praskiej Wiosny w 1968 roku). Dekada lat 70. XX wieku, obejmująca lata tzw. normalizacji w CSRS pod rządami I sekretarza KC KPCz (od 1975 roku także prezydenta) Gustáva Husáka i zmianę na stanowisku I sekretarza KC PZPR (Edward Gierek), przyniosła poprawę stosunków. Tradycyjnie dobrosąsiedzkie więzi wzmocnione z jednej strony międzynarodowymi tendencjami odprężeniowymi, i z drugiej prawnym instrumentarium stworzyły podatny grunt do rozwoju kontaktów kulturalnych. Współpracę filmową PRL-CSRS w latach 70. określały bezpośrednie porozumienia podpisywane co roku przez Naczelny Zarząd Kinematografii (NZK) Ministerstwa Kultury i Sztuki PRL i „Czechosłowacki Film”. Do najważniejszych przejawów kooperacji należały: koprodukcje, wymiana usług, uroczyste premiery z udziałem delegacji filmowców i imprezy kulturalne, takie jak: „dni” i „,tygodnie filmu” czy retrospektywy - organizowane wspólnie oraz na zasadzie wzajemności, a także uczestnictwo w festiwalach filmowych. Powstały dwa koproducenckie dzieła: Zaklęte rewiry (1975) Janusza Majewskiego i Krótkie życie (1976) Zbigniewa Kuźmińskiego. Ponadto Polska i Czechosłowacja były jednymi z koproducentów (wraz z Węgrami, Bułgarią, Rumunią i Niemiecką Republiką Demokratyczną) propagandowego filmu radzieckiego pt. Żotnierze wolności (1977) Jurija Ozierowa. Nie wszystkie plany zrealizowano. Współpracę komplikowała złożona, powstała w następstwie wydarzeń 1968 roku, sytuacja w filmowym środowisku twórczym CSRS i dogmatyzm tamtejszych władz. Jeśli chodzi o zakup i rozpowszechnianie filmów, różnice produkcyjne między kinematografiami (przewaga CSRS) i ostrożność strony czechosłowackiej powodowały, że Polska kupowała znacznie więcej filmów, przy czym były to, co charakterystyczne dla okresu „normalizacji”, głównie komedie, kryminały i baśnie, cieszące się sympatią polskiej widowni. Czechosłowackie zakupy polskich filmów fabularnych były mniejsze, zorientowane na filmy poprawne ideowo i neutralne politycznie, odbierając tym samym widzowi czeskiemu szansę, na poznanie osiągnięć artystycznych polskiej produkcji filmowej. Taka sytuacja wpływała z kolei negatywnie na wyniki rozpowszechniania filmów polskich na terenie Czechosłowacji. Ważną rolę w popularyzacji wzajemnych osiągnięć odegrały ośrodki kulturalno-informacyjne Polski w Pradze i Bratysławie, a Czechosłowacji w Warszawie oraz niezależne kontakty miłośników kina. 